\title{
Study on the Effect of Dictionary Use on Second Language Incidental Vocabulary Acquisition- An Empirical Study of College English Vocabulary Learning Strategy
}

\author{
Xiaohui Xu \\ School of Foreign Languages, Qingdao University of Science and Technology, Qingdao, China \\ E-mail: xxhqust@tom.com
}

\begin{abstract}
Vocabulary acquisition occupies a key position in learning a second language. How vocabulary is acquired and what the most effective means is to promote effective acquisition have been worthwhile lines of investigations in the field of SLA (Second Language Acquisition).But the study of the use of dictionary is relatively rare. Will the use of dictionary has positive effect on the IVA in reading the material without glosses? An empirical survey was carried out in order to test the influence of dictionary use.
\end{abstract}

Index Terms - incidental vocabulary acquisition, dictionary use, empirical study

\section{INTRODUCTION}

\section{A. The Concept of Incidental Vocabulary Acquisition}

IVA is first appeared in the study of children's acquisition of first language. The term incidental acquisition was first used in the field of psychology, but Incidental Vocabulary Acquisition was proposed by Nagy, Herman and Anderson in 1985 based on the research of how children acquire their mother tongue. Gass (1988: 198-217) observed that there were not agreed-upon definitions of Incidental Vocabulary Acquisition. It is of special importance to have a clear understanding of the term Incidental Vocabulary Acquisition.

\section{B. Questions and Hypotheses}

Based on the previous research findings and the English-learning situations in Chinese universities, the researcher of the study attempts to find answers to the following questions:

1) Will the use of dictionary has positive effect on the IVA in reading the material without glosses?

2) Will the paper dictionary and the electronic dictionary have different effect on the immediate word gains and retentions of learners?

\section{Empirical Study of Dictionary Use}

1. Marginal gloss and dictionary use

Gloss can be used as the easiest way to understand the meanings of words when they appear in context. Generally researchers agree that glosses facilitate reading comprehension and short-term vocabulary retention.

The most common means of dealing with unknown words in texts, as reported by the subjects, was to consult a dictionary: sometimes a bilingual dictionary, sometimes electronic dictionaries were reported. When consulting a dictionary, generally speaking, learners can learn the three dimensions of word identified by Aitchison (1987) as semantic, syntactic and phonological.

L2 learners often turn to dictionaries for help when reading texts. Although in recent years, many researchers, teachers, and textbook authors have encouraged students to guess, to use inference as the strategy of first choice, consulting in dictionaries still has its own advantages: for example, providing the learners with more information on the target word.

However, using the dictionary as the primary method of increasing students' vocabulary has not been proved by L1 research. Many of the L1 investigations were comparison studies between dictionary definitions and contextual guessing to see which condition best promoted the learning of new vocabulary.

Although the results showed that contextual guessing to be superior to dictionary definition, the findings were confounded by the fact that many of the texts, which were used for the context-only condition, provided definitions or examples for the targeted words.

2. Empirical study

\footnotetext{
* The paper is partial achievement of the college English teaching reform project "The construction of college English learning strategy guide mode and training models" of Shandong province in 2009 to2010. Project No.:EC201016.
} 
In Hulstijn et al.'s (1996: 327-339) study, the French participants, who were learning English, were asked to read a text with marginal glosses or with a dictionary. The results of the research show that the marginal glosses Group significantly out performed the Dictionary Group in the subsequent test of retention of the target words. In addition, the Dictionary Group students rarely had used the dictionary at all during the reading, but the relatively few words that were checked up in the dictionary during the reading task. The appearance of minimal dictionary use was because of the fact that advanced L2 learners' vocabulary size seemed to be large enough to get the global understanding of the text without using dictionary.

In Luppescu and Day's (1993: 263-287) research, 293 Japanese university students were required to read an English short story with a bilingual dictionary and without a dictionary. The students were allowed to take as much time as they needed to read the passage. Then 17 target words were tested by multiple-choice unexpectedly. The dictionary use Group did significantly better in the post test. However, the dictionary use Group took twice as much as the time. Further experiment is needed in this area.

\section{RESEARCH DESIGN}

The subjects are 60 freshmen who have been learning English as a second language in Qingdao University of Science and Technology.

\section{A. Methods}

\section{Selection of reading material}

The selection of English reading material as well as the selection of target words is crucial to ensure validity of the experiment. A reading passage from CET-4 training book was selected for the experiment (see Appendix I). It contained 10 unknown words (see Appendix I). In selecting reading material, several factors were taken into consideration. The passage was in an appropriate difficulty level to roughly match the learners' ability, that is, neither too difficult nor too easy, since students could only pay attention to a limited amount of information during a certain period of time and overloading the capacity of attention would lead to less likelihood in noticing and attention.

2. Selection of Target words

10 words from the reading text were selected as the target words. In selecting the target words, three steps were taken to make sure that words to be selected were unfamiliar to participants. First, the teacher marked the words which were considered to be unfamiliar to most of the participants.

The teacher selected 13 marked words which were believed by the teacher as unknown to participants. Then, a pilot study was conducted to further identify the unknown words. 11 words among the 13 were identified unfamiliar. Finally, one of the 11 words were removed for it is easy to be guessed out by the stem and affix, therefore 10 words were chosen as the target words, consisting of 5 nouns, 2 adjectives, 1 verb, 1 verb phrase and 1 adverbial .

\section{B. Procedures}

\section{Grouping}

The students are divided into two groups according to their score of English in college entrance examination so that the students of each group are similar in English proficiency and vocabulary size. They are group 1 and 2 . Group2 is also divided into two parts evenly. Students in part1 use the paper dictionary and students in part 2 use the electronic dictionary in the following task. The electronic dictionaries they use are learners' dictionaries, in which the information is not as specific as in the paper dictionary. Different groups are given different tasks:

Task One: Reading comprehension with glosses (group1).

Task Two: Reading comprehension without glosses while using dictionary (group2); half of the students use paper dictionary (part1 of group2), half of them use the electronic dictionary (part2 of group2).

2. Test of different reading tasks

The reading materials were handed out to the students according to their groups. They are allowed 15 minutes to do the reading comprehension without knowing the task of target word test. Each group has different task.

3. Immediate test and delayed test of target words

After the collection of the reading materials, they were tested on their knowledge of the target words.

The immediate test took about 5 minutes.

The subjects in the study were given an unexpected delayed target words test five days after they took part in the immediate test.

They were allowed 5 minutes to finish the test.

\section{Scoring and Data Analysis}

Each correct word is given one score both in immediate test and delayed test. The total score is 10 each time. The test papers were scored by the researcher. A word that was given the right Chinese meaning and part of word received a score of one. A wrong answer received zero.

The main instrument for the quantitative analysis is SPSS10.0. Descriptive statistics were conducted to present the sample numbers, mean scores and standard deviation for each group in the tests. The Independent-Samples T-tests were 
used to compare the scores of students with the paper dictionary and the electronic dictionary.

\section{RESULTS AND DISCUSSION}

A. Results of the Immediate Test of the Two Parts of Group 2

TABLE 3-1

DESCRIPTIVE STATISTICS OF THE IMMEDIATE TEST

Group Statistics

\begin{tabular}{|cl|r|r|r|c|}
\hline & GROUP & N & Mean & Std. Deviation & \multicolumn{1}{c|}{$\begin{array}{c}\text { Std. Error } \\
\text { Mean }\end{array}$} \\
\hline SCORE & 1 & 15 & 6.33 & 1.45 & .37 \\
& 2 & 15 & 7.20 & 1.52 & .39 \\
\hline
\end{tabular}

Notes: score1 is from partlof group3 (with the paper dictionary) score 2 is from part2of group3 (with the electronic dictionary)

The mean scores for the two parts respectively are 6.33 for part $1 ; 7.20$ for part 2 ; the table shows that students of part 2 get the higher mean score than students of part1.

TABLE 3-2

INDEPENDENT SAMPLES T-TEST RESULTS FOR THE IMMEDIATE TEST

Independent Samples Test

\begin{tabular}{|c|c|c|c|c|c|c|c|c|c|c|}
\hline & \multicolumn{2}{|c|}{$\begin{array}{l}\text { Levene's Test for } \\
\text { Equality of Variances }\end{array}$} & \multicolumn{7}{|c|}{ t-test for Equality of Means } \\
\hline & & \multirow[b]{2}{*}{$\mathrm{F}$} & \multirow[b]{2}{*}{ Sig. } & \multirow[b]{2}{*}{$\mathrm{t}$} & \multirow[b]{2}{*}{ df } & \multirow[b]{2}{*}{ Sig. (2-tailed) } & \multirow{2}{*}{$\begin{array}{c}\text { Mean } \\
\text { Difference }\end{array}$} & \multirow{2}{*}{$\begin{array}{l}\text { Std. Error } \\
\text { Difference }\end{array}$} & $\begin{array}{r}95 \% \mathrm{C} \\
\text { Interv } \\
\text { Diffe }\end{array}$ & $\begin{array}{l}\text { dence } \\
\text { f the } \\
\text { ice }\end{array}$ \\
\hline & & & & & & & & & Lower & Upper \\
\hline SCORE & Equal variances assumed & .054 & .818 & -1.598 & 28 & .121 & -.87 & .54 & -1.98 & .24 \\
\hline & $\begin{array}{l}\text { Equal variances not } \\
\text { assumed }\end{array}$ & & & -1.598 & 27.931 & .121 & -.87 & .54 & -1.98 & .24 \\
\hline
\end{tabular}

As we can see from table 4-12, the Sig. P. value (i.e., 0.121) is larger than 0.05, which shows that the Independent Samples T-test for the level of significance of means makes it clear that there is no significant difference between the two groups in the retention of the words.

B. Results of the Delayed Test of the Two Parts of Group 2

TABLE 3-3

DESCRIPTIVE STATISTICS OF THE DELAYED TEST

Group Statistics

\begin{tabular}{|rl|r|r|r|r|}
\hline & GROUP & $\mathrm{N}$ & Mean & Std. Deviation & \multicolumn{1}{c|}{$\begin{array}{c}\text { Std. Error } \\
\text { Mean }\end{array}$} \\
\hline NUMBER & 1 & 15 & 6.07 & 1.49 & .38 \\
& 2 & 15 & 5.27 & 1.71 & .44 \\
\hline
\end{tabular}

Notes: score1 is from partlof group3 (with the paper dictionary) score 2 is from part2of group3 (with the electronic dictionary)

The mean scores for the two parts respectively are 6.07 for part 1; 5.27 for part 2; the table shows that students of part 1 get the higher mean score than students of part 2 . 
TABLE 3-4

INDEPENDENT-SAMPLES T-TEST RESULTS FOR THE IMMEDIATE TEST

\begin{tabular}{|c|c|c|c|c|c|c|c|c|c|c|}
\hline \multicolumn{11}{|c|}{ Independent Samples Test } \\
\hline & & $\begin{array}{r}\text { Levene' } \\
\text { Equality o }\end{array}$ & $\begin{array}{l}\text { st for } \\
\text { riances }\end{array}$ & \multirow[b]{3}{*}{$\mathrm{t}$} & \multicolumn{4}{|c|}{ t-test for Equality of Means } & & \\
\hline & & \multirow[t]{2}{*}{1} & \multirow[b]{2}{*}{ Sig. } & & \multirow[b]{2}{*}{$\mathrm{df}$} & \multirow[b]{2}{*}{ Sig. (2-tailed) } & \multirow{2}{*}{$\begin{array}{c}\text { Mean } \\
\text { Difference }\end{array}$} & \multirow{2}{*}{$\begin{array}{l}\text { Std. Error } \\
\text { Difference }\end{array}$} & \multicolumn{2}{|c|}{$\begin{array}{l}\text { 95\% Confidence } \\
\text { Interval of the } \\
\text { Difference }\end{array}$} \\
\hline & & & & & & & & & Lower & Upper \\
\hline \multirow[t]{2}{*}{ NUMBER } & Equal variances assumed & .229 & .636 & 1.368 & 28 & .182 & .80 & .58 & -.40 & 2.00 \\
\hline & $\begin{array}{l}\text { Equal variances not } \\
\text { assumed }\end{array}$ & & & 1.368 & 27.468 & .183 & .80 & .58 & -.40 & 2.00 \\
\hline
\end{tabular}

As we can see from table 4-14, the Sig. P. value (i.e., 0.182) is larger than 0.05 , which shows that the Independent Samples T-test for the level of significance of means makes it clear that there is no significant difference between the two groups in the retention of the words

\section{Comparison between Group 1 and Group 2}

The mean score of immediate test for group2 (with the use of dictionary) is 6.77 , and the mean score for group1 (without the use of dictionary) is 3.06. It indicated that dictionary use has positive effect on IVA in immediate gain of new words.

The mean score of immediate test for group2 (with the use of dictionary) is 5.67, and the mean score for group1 (without the use of dictionary) is 2.47 . It indicated that dictionary use has positive effect on IVA in the retention of new words.

The result testified the hypothesis 1 to be true.

In Luppescu and Day's (1993: 263-287) research, 293 Japanese university students were required to read an English short story with a bilingual dictionary or without a dictionary. The dictionary use group did significantly better in the post test. The experiment got the same result of the former test of scholars.

It indicated that the Chinese L2 learners have relatively low guessing ability, so the training of this ability can be conducted in the English class. Students also can build their guessing ability spontaneously in the further study of English.

\section{Comparison between Part 1 and Part 2 of Group 2}

As shown in table 3-1 and table 3-3, there is no significant distinction between using the different kind of dictionary. But the retention rate of part1 is higher than part2 significantly. The followings are reasons for discussion.

There are large amount of vocabulary information in paper dictionary, such as phrases, model sentences, different part of words, etc. Electronic dictionary is more convenient than the paper dictionary but it has less interpretation of the words in all aspects than paper dictionary.

It shows that when students use electronic dictionaries, they only concentrate their attention on finding meaning to help them comprehend the text. They do not tend to elaborate the word deeply, compare it with pre-existing knowledge in mind, and construct a relationship between form and meaning. On the other hand, in the process of using paper dictionary, students may do more search and evaluation than students who use electronic dictionary. This process also contains more involvement load.

Therefore, in the long run, students in part2 (with electronic dictionary) tend to forget more of the words that they have stored in their short-memory than part1 (with paper dictionary).

The findings also partially support the involvement load hypothesis proposed by Laufer and Hulstijn (2001: 1-26).

\section{CONCLUSION}

Paper dictionary is useful for students in building good study habit. Students are encouraged to do more consultation while necessary.

On the other hand, when readers do notice the new words then look them up in dictionary or infer their meanings correctly in context, they can be stored longer in their memory. Therefore, all the four reading tasks have their own advantages in promoting learners' IVA, we cannot simply prefer one and ignore the others. Instead, it is advisable to choose suitable reading task or combine them together according to the specific situations.

Since the consultation of dictionary has a positive impact on vocabulary learning and reading development, it should be encouraged to use dictionary in a consistent and appropriate manner. Paper dictionary is better than electronic dictionary. In the process of meaning inference or dictionary consultation, words meanings can be elaborated more deeply and be easier to be remembered.

\section{REFERENCES}

[1] Aitchison. J. (1987). Words in the Mind. Oxford: Blackwell.

[2] Gass, S. (1988). Integrating Research Areas: A Framework for Second Language Studies. Applied Linguistics, 9:198-217. 
[3] Hulstijn, J. H. Hollander, M. \& Greidanus, T. (1996). Incidental Vocabulary Learning by Advanced Foreign Language Students: The Influence of Marginal Glosses, Dictionary Use, and Reoccurrence of Unknown Words. Modern Language Journal, 80:327-339.

[4] Laufer, B. (1997). The Lexical Plight in Second Language Reading. Cambridge: CUP.

[5] Laufer, B. \& Hulstijn, J. (2001). Incidental vocabulary acquisition in a second language: The Construct of Task-Induced Involvement. Applied Linguistics, 22(1): 1-26.

[6] Luppescu, S. \& Day, R. R. (1993). Reading, Dictionaries, and Vocabulary Learning. Language Learning, 43:263-287.

Xiaohui Xu was born in Zibo, China in 1977. She received her M.A. degree in Foreign Linguistics and Applied Linguistics from Ocean University of China in 2010.

She is currently a lecturer in the in the School of Foreign Languages, Qingdao University of Science and Technology, Qingdao, China. Her research interests include Second Language Acquisition and Foreign Language Teaching. 